\title{
Erratum to: Release from PI: An analysis and a model
}

\author{
D. J. K. Mewhort ${ }^{1} \cdot$ Kevin D. Shabahang • D. R. J. Franklin
}

Published online: 18 July 2017

(C) Psychonomic Society, Inc. 2017

\section{Erratum to: Psychon Bull Rev}

\section{DOI 10.3758/s13423-017-1327-3}

In the online published pdf, Figs. 10 and 11 are the same. This has been updated on the Springer site.

The online version of the original article can be found at http://dx.doi.org/ 10.3758/s13423-017-1327-3

$\triangle$ D. J. K. Mewhort mewhortd@queensu.ca

1 Department of Psychology, Queen's University, Kingston, ON, Canada 